Abstracta Iranica

Revue bibliographique pour le domaine irano-aryen

Volume 32-33 | 2013

Comptes rendus des publications de 2009-2010

\title{
Loiq Sheralī. Sadu yak ghazal. Ed. by B. Rahimī and A. Mūsoev
}

\section{Evelin Grassi}

\section{(2) OpenEdition \\ 1 Journals}

\section{Electronic version}

URL: http://journals.openedition.org/abstractairanica/40999

DOI: 10.4000/abstractairanica.40999

ISSN: 1961-960X

Publisher:

CNRS (UMR 7528 Mondes iraniens et indiens), Éditions de l'IFRI

\section{Printed version}

Date of publication: 1 December 2013

ISSN: 0240-8910

\section{Electronic reference}

Evelin Grassi, « Loiq Sheralī. Sadu yak ghazal. Ed. by B. Rahimī and A. Mūsoev », Abstracta Iranica [Online], Volume 32-33 | 2013, document 443, Online since 01 July 2016, connection on 27 September 2020. URL : http://journals.openedition.org/abstractairanica/40999 ; DOI : https://doi.org/10.4000/ abstractairanica.40999

This text was automatically generated on 27 September 2020.

Tous droits réservés 


\section{Loiq Sheralī. Sadu yak ghazal. Ed. by B. Rahimī and A. Mūsoev}

\section{Evelin Grassi}

\section{REFERENCES}

Loiq Sheralī. Sadu yak ghazal. Ed. by B. Rahimī and A. Mūsoev, Dushanbe, Irfon, 2009, 103 p. [101 ghazals]

1 These selections from the poetry of the poet Loiq Sherali (1941-2000) are published in a popular, inexpensive paperback series, which the publishing houses Irfon and Adib are using to circulate outstanding works by classical and modern Tajik-Persian poets. Loiq Sheralī, an important contemporary figure (especially after the breakup of the Soviet Union), worked to revive the Tajik language by setting up the Tajik Language Foundation, Bunyodi zaboni tojikī, on 19th July 1991. The Bunyod's mouthpiece was the magazine Somon, which has compiled lists of Tajik words for replacing Russian loanwords or words in Tajik that had been altered by Russian.

\section{AUTHORS}

\section{EVELIN GRASSI}

Université de Naples 